AFRICAN

\title{
AU-China peace and security co-operation: RECs, CSOs, and think tanks for the win
}

\author{
by Lina Benabdallah* \\ Center for African Studies, University of Florida \\ Gainesville, United States of America
}

\begin{abstract}
Extant literature points at peacekeeping troops, financial support of the African Peace and Security Architecture, and promoting development to be the backbone of China-Africa security engagements. However, despite notable growth in each one of these aspects over the past few years, there are concerns over Chinese ambitions and African agency in conflict resolution and stability maintenance. This article addresses the role that the African Union (AU) can play in enhancing, guiding, and evaluating China-Africa security co-operation. By taking security to encapsulate not only military but economic, human, and environmental dimensions, it becomes more evident that negotiations that are based on project evaluation and follow-up mechanisms lead to a sustainable development-security nexus. However, AU officials have expressed structural challenges within the AU Commission that hinder an efficient participation at China-Africa summits and other multi-lateral platforms.
\end{abstract}

*Lina Benabdallah is a doctoral candidate in International Relations and is affiliated with the Center for African Studies at the University of Florida. Her research focuses on Sino-African relations, development-security nexus, and SouthSouth power gaps. Her dissertation fieldwork (in China and Ethiopia) has been funded through several grants including the Center of African Studies predissertation grant, the political science department summer grant, and the Office of Research doctoral grant. 
AFRICAN

EAST-ASIAN

AFFAIRS

Consensus-building which is vital for a unified agenda as well as lack of means to set up follow-up mechanisms for development projects across over 50 member states are the big roadblocks. In brief, as a way to go around these two challenges, this study identifies the regional economic communities (RECs), Civil Socicety Organisations (CSOs) and think tanks as the key allies of the AU to maximise its potential at the negotiations table.

\section{Introduction}

"We believe that development is the foundation for peace in Africa (...) If Africa is to achieve durable peace and stability, it needs to speed up economic and social development". (Chinese foreign minister, Yang Jiechi, 2010. Remarks made at Second Round of Ministerial Political Consultations Between China and Africa)

Peace and security are now part and parcel of China-African partnerships, evidence of which can be found in the Forum on China Africa Co-operation action plans (FOCAC). The first explicit mention of official co-operation on peacebuilding a at FOCAC summit meeting was in 2006 in Beijing. It was then reinforced in the Fourth Ministerial Meeting in 2009 in Egypt, stating that China:

"will strengthen co-operation with countries concerned in the UN Peacebuilding Commission and support countries in their post-war reconstruction processes".

Moreover, in the Fifth Ministerial meeting of FOCAC held in Beijing in July 2012, China's engagement in African peace and security was made even more substantive with the establishment of the China-Africa Co-operative Partnership for Peace and Security. During this fifth summit, then President Hu Jintao, announced a five-point plan in which he vowed to:

"Deepen co-operation with the AU and African countries in peace and security in Africa, provide financial support for the AU peace-keeping missions in Africa and for the development of the African Standby Force, train more officials in peace and security affairs and train peace-keepers for the AU”. (Hu Jintao, FOCAC $\mathrm{V}, 2012)$ 


\section{AFRICAN \\ EAST-ASIAN \\ AFFAIRS

Likewise, FOCAC VI is expected to emphasise even closer co-operation on Peace and Security both bi-laterally and multi-laterally strengthening AU-China and Africa -China co-operation on this front. It is evident that the AU has a strong role to play in guiding China-Africa conflict resolution and stability promotion given the expertise of the AU Peace and Security Council (AUPSC) in African conflict resolution as well as other organs that contribute to long term stability through enhancing development, trade, education, and so forth. Additionally, with the formal inclusion of the AU as a member in FOCAC and the recent establishment of a Chinese dedicated diplomatic mission to the AU in March 2015, along with multilateral co-operation between China and African countries via the AU shows that the relationship has entered a more formalized phase.

There is an increasing body of China-Africa literature addressing different aspects of security co-operation. These include: the examination of the contribution of China to peacebuilding efforts and how that reflects on norm-making and norm following (Alden, 2014; Alden and Large, 2014); China's role in peace negotiations in South Sudan (Anthony and Hungkun, 2014; Large, 2008, 2009, 2015); discussing the noninterference principle in China's security motivations in Africa ( $\mathrm{Wu}$ and Taylor, 2011; Wang, 2013; Xu 2012); debates over China's reaction to the Responsibility to Protect and the crisis in Libya (Garwood-Gowers, 2012); and looking at the controversial Chinese arms exports to sub-Saharan Africa (Lynch, 2012; Hauauer and Morris, 2014). There is also a fair amount in the literature to highlight Beijing's advantages in having a clearly articulated Africa policy and that the lack of reciprocity of an Africa policy for China weakens many African states' negotiating capacities.

However the bulk of the existing literature talks about China-Africa security cooperation from a bi-lateral scheme and there is a gap in addressing the multi-lateral platform with the AU as a voice for African agency. To be sure, scholars such as Van Hoeymissen (2010) have tackled the role that Beijing plays in providing financial and technical support to African regional organisations ${ }^{1}$. However it remains to discuss the challenges that confront multi-lateral co-operation between China and African states. Thus, the goal of this paper is to build on existing works 
by filling in the gap of addressing the potential role of the AU in promoting ChinaAU-Africa peace and security co-operation. The paper does not stop at the conclusion that Africans need to have a stronger negotiating voice or that the AU has to come with a co-ordination plan for a more effective presence at FOCAC. Instead, this article explores the potential of AU-China peace and security co-operation by 1) giving an overview of the ways in which China contributes to African peace and security issues, 2) examining the role of the AU and the challenges it faces in exercising better agency in China-Africa co-operation, and 3) suggesting ways for the AU Commission to improve its negotiating capacity. Finally the article will conclude with a general discussion on the upcoming FOCAC summit.

\section{Overview of Beijing's security engagements in Africa: development-security nexus}

Beijing and the Commission of the AU seem to share a broad understanding of security in terms that are not strictly defined within a traditional paradigm implying military security, but more in-line with economic and human security. To be sure, the Joint Statement on Comprehensively Deepening China-AU Friendly Cooperation which followed Li Keqiang's visit in May 2014 consisted of twelve points of agreement only two of which directly mentioned peace and security. Yet, the entire document implied an emphasis on regional stability and promoting (nontraditional) security through actively improving the continent's food security with better agricultural co-operation, achieving socio-economic developmental goals as well as other Agenda 2063 items $^{2}$. Additionally, the joint statement committed the AU Commission to actively contribute to "China's endeavour to build a moderately prosperous society in all aspects and achieve the Chinese dream" (African Union, 2014). As summarised by Bill Bishop (2013) the Chinese dream is as a dream of "national rejuvenation, improvement of people's livelihoods, prosperity, construction of a better society and military strengthening" (China Insider, 2013). Evidently, Agenda 2063 and the concept of the Chinese Dream both seek the common goals of development and prosperity. By the same token, framing the joint declaration in terms of these two concepts of the Chinese dream and the AU's Agenda 2063 highlights the interest in a two-way partnership. However China's interest in 


\section{AFRICAN \\ EAST-ASIAN \\ AFFAIRS

promoting development and fighting inequality preceded China-Africa and ChinaAU co-operation.

Beijing has historically been an adherent of the development-security nexus approach. Since Deng Xiaoping and the "industrial revolution era" of China (post 1970's), the Chinese Communist Party (CCP) had increasingly put a premium on enhancing development, reducing poverty, and providing jobs as measures to ensure relative stability in the country.

In addition, the concept of "new security" is based on a shift from understanding security as self-help to a more mutual/common security (China Report, 2002). Since the late 1990s China has embraced a progressive view of security (at least discursively) which was not based on a Cold War zero/sum mentality but instead on common and mutual security based on diplomatic dialogue and a win/win mentality. The Chinese Defence White Paper from 1998 is one of the earliest official documents that explicitly stated that security cannot be guaranteed:

"by an increase in arms, or by military alliances. Security should be based on mutual trust and common interest. [...] We should solve disputes through peaceful means and strive for common development." (Chinese Defence White Paper, 1998)

Furthermore more recent versions of the "New Security Concept" (xin anquan guandian) hone in on the non-traditional humane security which views threats as not just military or political but also environmental, epidemiological, diaspora-related, and so forth. As expressed by President Xi Jinping the New Security Concept means that "development is the greatest form of security" (People's Daily Online, May 21 - see also China Brief, May 23) ${ }^{3}$. The concept focuses on the importance of achieving a collective win-win security model that is based on a harmonious coexistence rather than hegemony and an arms race ${ }^{4}$. Indeed, a Chinese official position paper confirms adherence to a two-sided approach to security in which mutual development, trust, and win-win are central ${ }^{5}$. The latest document on China's military strategy (released on May, $25^{\text {th }} 2015$ ) equally echoes Beijing's commitment to peaceful development but also adds an emphasis on the need to protect China's interests abroad (be it nationals or economic investments $)^{6}$. 
AFRICAN

EAST-ASIAN

AFFAIRS

Furthermore, Chinese President Xi Jinping emphasised a continuation of this development-security nexus when he stressed that to build security:

"we need to focus on development, actively improve people's lives and narrow down the wealth gap so as to cement the foundation of security. We need to advance the process of common development and regional integration, foster sound interactions and synchronised progress of regional economic co-operation and security co-operation, and promote sustainable security through sustainable development". (Xi Jinping, 2014)

This way of thinking about the relationship between security and development is also reflected in Chinese foreign policy and its stand on what peacebuilding strategies in Africa should be like. As put by the Chinese Foreign Minister (2013):

"when conducting diplomacy, we must be fully committed to development, which holds the key to numerous problems in the world". (Wang Yi, 2013)

Such strong emphasis on the efficacy of economic development in achieving peace and stability reflects Beijing's practices domestically whereby the CCP, partly at least, draws some legitimacy and stability from providing satisfactory development rates and progress. However, when it comes to understanding the Chinese government's extrapolation of this development-leads-to-security internationally, Alden and Large (2013:23) view this as an expression of China's partaking in the "formative process of "norm making". Alden and Large argue that these norms (including economic development priority over democracy; facilitating the implementation of African home-grown solutions to African problems; and state centrality in the international system) are guidelines shaping China's alternative approach to peacebuilding (ibid: 24). Contrary to what could be described as a traditional "Western" liberal model for peacebuilding which rests on a firm belief that good governance via liberal democracy is the foundation for human rights and security, China has rather emphasised the priority of development over good governance ${ }^{7}$. Indeed for Chinese scholars like $\mathrm{Li}$ Anshan, China's support of development projects such as providing clean water supplies and enhancing local African food security are China's ways (albeit indirect) in reducing conflict and 
establishing security. In addition, Liu Hui and Xuejun (2005) much like Li Anshan, have argued that "development, stability and harmony is more attractive" than "democracy, freedom plus market economics for Africa" (Xuejun, 2010).

Along similar lines, Wang accounts for China's peacebuilding contributions by asserting that:

"development can be tied to post-conflict reconstruction measures", and that in fact, "China participated in the post-war reconstruction of many African countries, including Sierra Leone, Liberia, Sudan, Angola, Congo (DRC), and so on. The process involved the Chinese government, China Development Bank, largescaled SOEs at state and provincial levels as well as private businesses "8(Wang, 2013:80)

Hence, development goes hand in hand with peacebuilding efforts. Channelling such discourse about the priority of development and stability over democracy and other Western liberal ideologies, the Chinese government follows up with practices including but not limited to deploying peacekeeping teams that consist of engineers, doctors, farmers, and other non-combat troops. Many times the missions of these non -combatant troops include providing drinking water to the population, building basic infrastructure, and setting up small medical facilities for rural populations. Further illustrations of these missions, for example taking on a project to build several hundred housing units designated to lodge military families in Eastern Africa, are also framed as contributing to African peace and security ${ }^{9}$. Although this initiative does not mandate Chinese peacekeepers to be involved in conflict directly, it does provide support to the local forces by building necessary housing units or by financially contributing to related expenditures. Caring for the well-being of African populations by ensuring basic development goals, then, implies for the Chinese foreign policy, providing and improving security.

This is of course not to overlook important other initiatives that are less directly related to development than to a more material military security. The debates around a potential base in Djibouti, the naval presence in Somalia as well as the variety of Beijing-sponsored (technical and logistical) training programmes for African 
militaries are some examples of Beijing's wide interest in Africa's security concerns, but these are beyond the scope of this paper.

However, this approach of viewing security enhancement as an implication of a multitude of development projects and foreign direct investment in Africa is not without negative consequences on stability. Indeed development empowerment without paying attention to governance and peacebuilding might entail the risks of governments using financial ties with China as leverage against their own citizens. More generally, development projects that are not inclusive of all concerned parties and that marginalize some groups at the expense of development, fuel discontent and instability ${ }^{10}$. Moreover, concerns related to land grabs and food security -although better if not exaggerated- could potentially fuel more conflict and grievances. Other risks of creating conflict as a result of implementing mega infrastructure projects can be illustrated in certain development projects sponsored by China Ex-Im Bank which ended up proving to bare negative consequences for indigenous populations. Examples of this include building a huge Dam in Sudan which caused the displacement of no less than 50000 people, and also Dam Gibe 3 in Ethiopia which caused further impoverishment of ethnic (and highly armed) groups along the Turkana lake ${ }^{11}$. Easier flow of traded goods between Chinese and East African ports has also facilitated the expansion of illegal trade in Chinese-made weapons and armaments often used in conflicts that Chinese foreign policy puts a great effort into solving (Attree, 2012; Leff and LaBrun 2014). These examples show that there is a need for a better co-ordination and evaluation mechanisms to determine the potential risks and benefits of implementing big investment projects. It is the argument of this article that the AU has an important role to play in co-ordinating evaluations and follow-up mechanisms.

\section{China's creative engagement in Africa's security}

The Chinese government is willing to improve its expertise in handling security issues in Africa and that it is developing new strategies to cope with situations as it goes (Benabdallah, 2014). There is, in other words, no evidence to support the existence of a military grand strategy for China-Africa, but there is most definitely 


\section{AFRICAN \\ EAST-ASIAN \\ AFFAIRS

strategic thinking in terms of playing a bigger role in African security issues. Necessarily in the absence of a grand strategy, then, there is a need for conducting foreign policy on a case by case approach and a great deal of monitoring and adapting to individual situations. Wang $\mathrm{Yi}$ developed the term "creative involvement" in security issues to describe a pragmatic and innovative approach to foreign policy practices (Duchâtel, Bräuner and Hang, 2014:9).

Some examples of such creative strategies in Africa entail a military diplomacy presence with sending permanent military attaches to eleven countries (so far quite modest but it could expand) and welcoming 28 African defence attaches to Beijing (Shinn, 2014). Another innovative strategy is sending peacekeeping troops that are trained to cope with armed conflicts to the conflict zones that are home to large Chinese investments. This was seen when in September 2014 China added some 700 combat troops to its contribution to UNMIS in South Sudan in order to carry out the UN mandate and at the same time provide security for Chinese investments and assets in the country. In a press conference given by China's Defence Minister in late September 2014, Spokesperson Geng Yansheng was asked whether the infantry battalion was just sent to carry out the humanitarian mission or to protect Chinese interests, his answer emphasized China's respect of the UN mandate but did not reject the possibility of this battalion being involved in protecting foreign nationals in need. However given the fact that the Chinese government is concerned with trust building vis-à-vis its relation to African states as well as the international community, it is cautious not to mix humanitarian interventions with having "boots on the ground" to protect its national interests on African soil. Even the alleged talks about establishing a Chinese military navy base in Djibouti have taken a "responsibility to protect economic interests" spin in order to maintain Beijing's commitment to respecting African sovereignty and differentiating its initiative from existing United States of America (USA) and French bases in Djibouti ${ }^{12}$.

Beijing's recent efforts to participate in African peace and security through promoting post-conflict reconstruction projects are indicative of its willingness to promote its own model of development based on a broad adherence to the development-security nexus. Indeed until recently, as expressed by Alden and Large 
AFRICAN

EAST-ASIAN

AFFAIRS

(2013), "China has been mostly a footnote in the burgeoning international attention towards post-conflict reconstruction and peacebuilding," but the situation is changing gradually. One of the main reasons of China's marginal performances in peacebuilding is related to China's history of adherence to the non-interference principle. Consequently, traditionally China's peacekeeping co-operation with African states has been more prominent than peacebuilding because the former is less controversial and reasonably reconcilable with China's non-interference policy. However, as Alden and Large argue, China's participation in debates on financial contributions to the UN Peacebuilding Fund and other similar mechanisms is a teller of China's willingness to be more proactive on this front.

Lu Shaye, the Director General of the Ministry of Foreign Affairs' (MFA) Department of African Affairs, has argued that Beijing adopts the tactic of "constructive involvement" on the basis of non-interference (Duchâtel et al, 2014). In his analysis, Lu Shaye makes the case that Beijing's adherence to the noninterference principle cannot remain rigid but has to become flexible. The concept of "constructive involvement" which he puts forward is based on two aspects: first, getting involved in security crises following UN guidelines and host country's agreement; second, and this is the innovative part, getting involved in a constructive way means playing a positive role in African security issues instead of taking a domineering role as traditional powers usually do. According to Lu Shaye, Beijing has been constructively involved through these main channels: participating in direct conflict mediation, supporting UN or African regional organisation-led peace talks, supporting regional peacekeeping missions, and participating in maintaining peace and stability through development projects (Duchâtel et al:2014). Indeed as noted by Alden (2014:4), China was a traditional sceptic about peacekeeping missions and has been known for vetoing and resisting multi-lateral collective action mechanisms. However, since 1990, which is China's first contribution to peacekeeping, its position has changed from blocking the missions at the UNSC to actively participating in many and in fact to topping the UNSC in terms of contributing with largest PKO teams. As expressed by Li Keqiang in his speech to African Union staff in Addis Ababa, "China has contributed more personnel to UN peacekeeping 


\section{AFRICAN \\ EAST-ASIAN \\ AFFAIRS

operations in Africa than other permanent members of the UN Security Council, and Chinese peacekeepers are serving their duties in multiple hotspot areas across the continent. The solidarity and mutual trust between China and Africa serve not only our respective development but also peace and progress of the world" (China Daily, 2014). Chinese peacekeepers have indeed participated in nine out of the current 15 UN peacekeeping operations around the world. While the number of Chinese peacekeepers worldwide is much smaller than that of Bangladesh (10,757), India $(8,919)$ and Pakistan $(10,656)$, China currently ranks as the largest contributor to UN peacekeeping operations among the five permanent members of the UNSC. With regards to Africa, since the 2006 FOCAC Summit, China's deployment of peacekeeping troops and police to Africa has totalled 6,281 person-time, with 1,629 Chinese soldiers and police officers remaining in service in six UN peacekeeping missions in the region. As the chart below shows, China's participation with peacekeeping troops has been increasing since the early 2000. However, is contributing with peacekeeping troops enough to achieve the level of stability and security co-operation that FOCAC agendas aim for?

\section{AU-China security co-operation: no more than marginal?}

Alden argues that Beijing faces a three-fold risk with regards to non-engagement in security issues in Africa. A reputational risk to China's image abroad as a responsible emerging power due to engaging with unpopular regimes, a risk to its business interests in less stable regions, and a risk to its nationals living across the African continent in areas that are prone to conflict (2014:1). Hence, juggling demands and willingness to be more assertive on the international security scene with Chinese foreign policy principles of respecting state sovereignty often prove challenging. For this reason closer co-operation with the AU commission provides Beijing an opportunity to tap into the expertise of the African Union Pease and Security Council (AUPSC) and its knowledge of the intricacies involved in different conflicts. Effectively since the passing of Article 2 of the Constitutive Act in 2002 which transformed the Organization of African Unity into the AU, peace and security issues have been tackled under the auspices of the five-pronged system of The African Peace and Security Architecture (APSA) composed of the Peace and 
AFRICAN

EAST-ASIAN

AFFAIRS

Security Council (PSC), the Early Warning System (EWS), the African Standby Force (ASF), the Panel of the Wise, the Peace Fund and the designated regional economic communities (RECs). Besides, some of the functions included in the AUPSC mandate consist of preventive diplomacy, peace-making, peacebuilding, and humanitarian intervention (African Union Protocol, 2003). However, one of the main challenges facing this apparatus is the existential dilemma that is characteristic of most inter-governmental organisations; autonomy. The AU in general and the AUPSC more specifically relies on financial, equipment, and logistical contributions of member states to have an efficiently operating EWS, and skilled expertise for the ASF. It follows that the financial situation being as it is with over 90 per cent of AU's operating budget coming from Western countries, financial autonomy is a challenge. Indeed, the AUPSC holds closer affinities to EUPSC and UNSC with which it holds Joint Field Missions like the recent one to Mali in February 2015 mostly because of the contributions and expertise provided by the European counterparts. Likewise, even on a more symbolic level, the new Peace and Security building at the AU headquarters in Addis Ababa is commissioned and financed by the German Federal Office with a value of over $€ 27$ million. The new building will be equipped with state-of-the-art equipment to enable a proper functioning of the Continental Early Warning System (African Union press August, 2012). For these reasons both Beijing and the Commission of the AU would benefit from furthering co-operation in Peace and Security. Necessarily, Beijing's willingness to participate with expert training for African Standby Force staff, as well as with equipment and armament is welcomed by AU officials. Yet by the same token, by putting security in the broader definition of development-as-security one can identify broader areas for China-AU co-operation and longer-term security goals.

\section{FOCAC as platform to enhance AU-China security co-operation}

The AU was admitted as a full member of FOCAC (Forum on China Africa Co-operation) on October 26, 2011. And as a matter of fact, Beijing played an important role in pushing for the AU to upgrade its status at FOCAC from an observing member to full status membership. This signifies China's interest in exploring multi-lateral co-operation in addition to bi-lateral tracks. It also sends 


\section{AFRICAN \\ EAST-ASIAN \\ AFFAIRS

signals to African counterparts that Beijing is being open to a more unified African agenda and willing to accommodate AU suggestions. Yet, China-Africa experts Alden and Large (2013:20) lament that despite FOCAC V being inclusive of the AU as a full member:

"the extent and nature of China's engagement with Africa's security and post -conflict peacebuilding institutional architecture, from the AU Peace and Security Council, conflict early warning system, Peacebuilding Support Facility or Panel of the Wise, to the facilities of the African Development Bank, NEPAD or the AU still remains unclear". (Alden and Large, 2013:20).

Indeed, even towards the end of FOCAC V and well into FOCAC VI there has not been clear agenda on how China will engage directly with post-conflict peace-building architecture. In this particular situation, all necessary mechanisms for co-operation seem to be in place; the discourse of Chinese foreign policy is very encouraging for a win-win and equal relations, the platform of FOCAC is very consultative and open to communication, and the inclusion of the AU as a member tops all these mechanisms. Therefore, there needs to be a proactive role played by the AU to maximise African agency in China-Africa co-operation in general and to achieve security goals in specific. In what follows the paper examines the challenges that AU officials pointed out in a series of interviews conducted at the AU Headquarters (Benabdallah, 2015b). After going over these challenges, the article proceeds with recommending ways to circumvent these challenges.

\section{AU's challenges in promoting African agency in FOCAC}

During preparatory and brainstorming phases that precede each China-Africa summit, the commission of the AU gives mention of several ideas and proposals that are in line with its strategy. For instance, in preparation of the ministerial official meeting in South Africa for FOCAC VI, some of the key issues that are highlighted by the AU Commission's promoting Agenda 2063 are development goals including an emphasis on gender empowerment, regional stability, more investment in renewable energies and industrialisation (Benabdallah, 2015b). When these proposals have been put forward, the Chinese side sends a draft of the action plan to 
AFRICAN

EAST-ASIAN

AFFAIRS

the AU Commission which forms a sous-committee consisting of 15 member-states (currently presided over by Chad). The sous-committee is in turn divided into working groups that will convene in order to discuss the action plan and make necessary remarks or suggest amendments. Then the office of the Permanent Representatives' Committee (COREP), which has a mandate to speak on behalf of all member-states, reviews and incorporates feedback from the working groups' reports and sends the action plan back to the Chinese side. Hence the AU is in a position to carry parallel communication channels. One is internal and goes to the representative missions of the member-states and the other is external and goes to different partners (China in this case). This structure of communication presents challenges to the AU which the next section examines in detail.

After having described largely how the process of crafting the FOCAC Action Plan unfolds on the African side, it helps to identify the AU's negotiations weaknesses. There are two key challenges that the AU has to overcome for a more efficient participation at FOCAC: consensus-building and follow up mechanisms. The first challenge is a concern mainly during the drafting of FOCAC agenda as the Commission of the AU has to survey different member states' voices and make somewhat of a coherent agenda draft. Managing as many diverse concerns into one platform or agenda was highlighted as a big challenge in my conversations with AUC partnership officials. Indeed, close to fifty African countries have formal trade relations with China and carry most of them bilaterally. For the AU to negotiate a strong and unified multi-lateral agenda and present it on behalf of its member states is indeed a challenging and lengthy process. Not the least because actual communications with all members is a time consuming challenge.

Meanwhile, the second key challenge which is perhaps even more pressing is related to the lack of having a mechanism in place to follow up on implemented projects or evaluate the cost and value of past or present deals. This is different from consulting on the values and risks of conducting business. Instead, follow up mechanisms are tasked with evaluating already implemented projects and assessing the extent to which they yielded expected results. The AUC, as it were, does not have effective ways of collecting data or evaluating for itself China-Africa projects to provide 


\section{AFRICAN \\ EAST-ASIAN \\ AFFAIRS \\ THE CHINA MONITOR}

insights on what has worked for the best interests of its member states and what needs improvement, amendments, or renegotiations. Instead, it relies on receiving progress reports from member states but is not mandated to oblige them to have or send said reports. Evidently, for the commission of the AU to be a proactive member of the preparatory as well as follow up China-Africa summit committees, it needs to have a clear sense of the status and effectiveness of development projects and other partnerships implemented through FOCAC platforms. Hence, maximising opportunity to realise Agenda 2063 goals through partnerships with China (as well other countries) is hinged upon evaluation and follow-up mechanisms. However, in conversations with several AU representatives, getting information about project evaluation reports remains challenging for the Commission. The AU as it stands does not have its own mechanisms or teams to lead project evaluation neither does it have enforcing powers to mandate member states to implement such mechanisms when they don't exist. It can suggest and raise issues to the attention of member states, it can also request reports but it's constrained to do more. For these reasons, and for financial autonomy challenges discussed above, the AU Commission (AUC) with its African Peace and Security department and its trade and investment sector would be better served being resourceful in getting data on partnership evaluations. The next section outlines some ways for the AU to circumvent these challenges and promote a proactive role in negotiations.

\section{A pragmatic way forward}

This study has so far established that collecting evaluation reports on China-Africa development projects that are completed or are in the realization process proves to be a particularly difficult endeavour because member states have different mechanisms for project evaluations. In some countries, it is at the level of foreign ministry that one can get data on development project evaluations, in others it is at the presidential office level, or in other decentralized governments it's at the level of local government offices all together. The same applies to AUC's calls on member states to share details about their bi-lateral security co-operation with China whereby the AU can only request information that member states will or will not volunteer. Thus, a question that begs to be asked is how to move forward knowing that AUC does not 
AFRICAN

EAST-ASIAN

AFFAIRS

have a standard coherent follow-up mechanism to facilitate the aggregation of evaluation reports and data? This article proposes three ways ahead that could make the AU-China partnership more conducive to improving Peace and Security partnerships based on Agenda 2063 and the Chinese concept New Security.

First, one way to remedy for this lack is for the AU Partnership division to strengthen ties to African civil society organisations and entertain regular meetings with relevant representatives. Often times, civil society organizations have hands-on evaluation reports on different development projects and their impacts (positive and negative) on local populations, existing grievances and so on. Countries such as Uganda, Kenya, Tanzania, Senegal, and Cameroon among others have a wealth of resources and research conducted by civil society organisations which can be of use to inform the AU's negotiations with trading partners ${ }^{13}$. Indeed when it comes to developmental mega projects, and especially in light of the above-mentioned examples of the grievances caused by dam constructions in the Sudan and Ethiopia, civil society groups should be involved in the process of weighing in the benefits and risks of such big projects. Furthermore, civil society groups have a better idea on the way to mediate conflict in places where conflict exists and can be used as references when the AU is negotiating ways for Beijing to support conflict resolution projects in Africa. Local NGOs have the merit of being able to cater solutions that work for their specific context and have better chances at achieving targeted results than standardised (one-size-fit-all) solutions. Following Beijing's support of the slogan African solutions to African problems, one can see how civil society groups can be the right channels for the AUC to strengthen its negotiating capacity with parties interested in playing a significant role in African peace and stability.

Second, think tanks can also serve as a valuable resource for consultancy on development project evaluation for the purpose of gaining a good grasp of what is happening on the ground. The list of think tanks ${ }^{14}$ that was recently released shows that Kenya, Ethiopia, South Africa, Senegal, Egypt, and Uganda are leading African countries in having world class think tanks. By working in tandem with an AU partnership unit and advising on specific projects, there could be a valid way to make up for the lack of standardised and accessible follow-up mechanisms for the AU. 


\section{AFRICAN \\ EAST-ASIAN \\ AFFAIRS

Furthermore, the already existing $10+10$ platform of China-Africa Think Tanks which facilitates information sharing and collaboration between Chinese and African think-tanks can be a valuable resource for the AU commission to tap into.

Additionally, a few of these think tanks are based in Addis Ababa providing a convenient proximity to the AU for even closer communication channels. Relying on reports from these think-tanks has the potential of conducting solid need assessments and proposing development projects that are inclusive of all local and indigenous groups. This is vital for advising policies on executing mega development projects which may have large negative unintended consequences on food security, ethnic tensions, and indigenous populations' livelihoods. In addition to this, think-tanks such as the Institute for Security Studies are very active in holding roundtables that join both scholarly as well as policy professionals to discuss mediation processes and conflict resolution roadmaps for Africa. The AUC can definitely benefit from regularly cooperating with such channels for better information on how to negotiate ways for Beijing to be effectively supporting African peace and security initiatives.

Last but not least, another way to circumvent the lack of evaluation mechanisms is to further strengthen the AU's co-operation with Africa's Regional Economic Communities (RECs) on the question of project evaluation. Indeed an additional way to go around the challenge of communicating with as many different member states and their progress reports is to convene a partnership with the EAC (East African Community), Economic Community of Central African States (ECCAS), Economic Community of West African States (ECOWAS), Intergovernmental Authority on Development (IGAD), and the Southern African Development Community (SADC).

The AU designated a total of eight Regional Communities through the AU-REC Protocol of 1998 but only five of them (those listed above) are active as the Arab Maghreb Union (UMA) suffers strenuous relations between Morocco and the AU over Western Sahara, the Kaddafi-instigated Community of Sahel-Saharan States (CEN SAD) withered, and The Common Market for Eastern and Southern Africa (COMESA) did not make substantial progress. Indeed the RECs are viewed as the AU's key implementing force and development agents that promote inter-regional 
AFRICAN

EAST-ASIAN

AFFAIRS

integration and facilitate trans-border social and economic co-operation. Yet, building on Van Hoeyemissen $(2010,2011)$ we propose here to view RECs as a valuable source of consulting on project evaluation and risk assessment. RECs transregional nature is conducive to permitting a smoother flow of information and coordination to get progress reports. In fact as Hoyemissen points out, "in 2005, China appointed representatives to SADC, ECOWAS and COMESA" (2011:57). At the very least, this signals Beijing's interest in carrying out its commitment in the FOCAC 2003 action plan to:

"provide, within the limits of its capabilities, financial and material assistance as well as relevant training to the Peace and Security Council of the African Union. In order to strengthen the capacity of African States to undertake peacekeeping operations, we look forward to the strengthening of China's co-operation with African states and sub-regional organizations in the areas of logistics." (FOCAC, 2003)

Again, it has been the goal of this paper to acknowledge important discursive moves to better the AU's role in channelling a strong and solid negotiations capacity with China as well as other partners, but also to move beyond rhetoric and propose concrete ways of improving the AU's efficacy in this regard. Thusly, more and regular co-operation venues need to be facilitated between the AU, China, and Africa regional organisations.

Arguably, the AU's partnership division can diversify its collaboration with nonstate actors and organize consistent symposia inviting different stakeholders to the table, from think tank affiliates, to civil society activists and regional organisation representatives. Such encounters ensure that the AUC is debriefed on current projects' progress status and will definitely maximise the AU's follow-up reports and improve its opportunity to be efficient at FOCAC table. The advantage of FOCAC fora is that they are systematic and have been a consistent platform for over a decade. This means that there has been enough time to observe and conduct evaluations of the projects and partnerships which were agreed upon in the earlier FOCAC summits. Another advantage of FOCAC is its structure with pre and post- 


\section{AFRICAN \\ EAST-ASIAN \\ AFFAIRS

follow-up committees which invites for a mechanism of evaluation to be implemented on both sides. FOCAC's structure as well as Beijing's willingness and insistence on giving the AUC full membership at FOCAC (as opposed to observing member which was the AU's status prior to 2011) are conducive for a stronger and more assertive voice of the AUC. Thusly, by tapping into the resources of RECs, CSOs, and think tank researchers, the AU can be well equipped to take a proactive role in negotiating partnerships not only with China but also with other partners.

\section{Concluding remarks: what role for the AU in FOCAC VI and beyond?}

Recently, Beijing has opened a dedicated mission to the AU becoming the second country (after the US) to have such formalised close ties to the AU. The mere fact of having a Chinese ambassador to the AU will facilitate communication channels and closer partnerships (Benabdallah, 2015b) Contra bi-lateral agreements that China signs with individual countries in Africa, the multi-lateral MOU it signed with the AU, in tandem with Agenda 2063, aims at increasing intrastate projects and cross country railway construction, aviation, infrastructure, and poverty reduction programs. These are different from bi-lateral agreements in that the speed train construction projects that are negotiated at the multi-lateral level are mega-projects that involve crossing through multiple countries and therefore need a strong coordination from the part of the AU. Besides strengthening these multi-lateral projects, the $\mathrm{AU}$ is pushing for renewable energies co-operation, industrialisation and technology updates, trade in finished goods produced in the continent, and making sure the win-win co-operation principle achieves its full potential.

To conclude, this article has argued that necessary mechanisms for enhancing African agency and unity through AU-China co-operation are already in place. Yet they are underexploited and overlooked. This article has argued that both a discourse encouraging more African agency as well as policy designed to enhance the AU's role in China-Africa relations already exist. Indeed, being a full member of FOCAC gives the AU opportunities to undertake more unified and stronger negotiations with China. In order to fulfil this potential, three ways of improving evaluations and follow up mechanisms have been proposed here. Moreover, in general terms, 
AFRICAN

EAST-ASIAN

AFFAIRS

engaging in better negotiations that are based on informed evaluation mechanisms and progress reports will in the medium to longer term achieve development potential in many conflict zones and reduce the risk of causing unanticipated grievances and instability.

\section{Endnotes}

1. For more on this refer to: Van Hoeymissen, S.2010. China's Support to Africa's Regional Security Architecture: Helping Africa to Settle Conflicts and Keep the Peace?. The China Monitor, 49:10-14.

2. Agenda 2063 (A Shared Strategic Framework for Inclusive Growth and Sustainable Development) is a fifty-year plan for socio-economic transformation and technological development. The strategy charts 50 years of growth and development following grand lines towards integrating African local and regional markets, achieving peace and stability, and sustainable development. (For more view: http:// agenda2063.au.int/en//vision).

3. President Xi Jinping gave this speech at the Conference on Interactions and Confidence-Building in Asia on 20 May 2014.

4. China's (2002) Position Paper on the New Security Concept explains that "under the new historical conditions, the meaning of the security concept has evolved....extending from military and political to economic, science and technology, environment, culture and many other areas". (For more information view: http:// www.china-un.org/eng/xw/t27742.htm).

5. (For more information view: http://www.fmprc.gov.cn/mfa_eng/zxxx_662805/ t1159951.shtml).

6. (For more information view: http://news.usni.org/2015/05/26/document-chinasmilitary-strategy). 


\section{AFRICAN \\ EAST-ASIAN \\ AFFAIRS \\ THE CHINA MONITOR}

7. In a speech at the Second World Peace Forum, Chinese foreign minister Wang Yi reiterated Chinese diplomacy's position regarding the centrality of the development agenda: "when conducting diplomacy, we must be fully committed to development, which holds the key to numerous problems in the world." (Chinese Ministry of Foreign Affairs. 2013. Exploring the Path of Major-Country Diplomacy With Chinese Characteristics [Online]. Available: http://www.fmprc.gov.cn/mfa_eng/ wjb_663304/wjbz_663308/2461_663310/t1053908.shtml (2015, June 29).

8. Wang (2013: 80) adds that "the development of Sino-African relationship provided an important opportunity for China to promote and strengthen such an image. Through peacekeeping missions, counter-piracy operations and weapon proliferation prevention efforts in Africa, China not only contributed to Africa's peace and security processes, but also achieved quite a success in public relations".

9. The Chinese government handed the project over in November 2014, providing 12,000 housing units constructed for Tanzania's military families, and took on a new project of building a military academy for Tanzania. (For more information view: http://www.independent.co.ug/news/news-analysis/9497-is-it-time-for-a-china-africa -command).

10. The author would like to thank her reviewer who suggested that there are examples of countries where GDP grows while conflict continues. The Sudan is a prime example of this in the sense that its GDP increased significantly due to oil trade with China, even though conflict has not withered. GDP size so to speak does not equal peace and stability and the relation between governance and development needs to be two-way and work in a feedback loop.

11. For more information on the concerns of food security threated by Dam Gibe 3 please view: http://allafrica.com/stories/201205140235.html. In addition, a series of analytical pieces can be found at: http://allafrica.com/view/group/main/main/ id/00011237.html. For more information on the Sudan's Dam creating ethnic tensions please view: http://www.internationalrivers.org/blogs/227/new-chinese-dam -project-fuels-ethnic-conflict-in-sudan. 
AFRICAN

EAST-ASIAN

AFFAIRS

12. (For more information on the implications of China's base in Djibouti refer to: http://africasacountry.com/what-does-it-mean-that-china-has-a-military-base-indjibouti/)

13. (For more information view: http://www.unctadxii.org/Documents/ UNCTADXII/uxiidom_cso001_en.pdf).

14. (For more information view: http://guides.library.harvard.edu/content.php? pid $=481539 \&$ sid $=4889044$ ).

\section{Bibliography}

Alden, C. and Large, D. 2013. China's Evolving Policy towards Peace and Security in Africa: Constructing a new paradigm for peace building? In Gebrehiwot Berhe, M. and Hongwu, L. (eds.) China Africa Relations: Governance, Peace, and Security. Addis Ababa University: Institute of Peace and Security Studies. 16-29.

Alden, C. 2014. Seeking security in Africa: China's evolving approach to the African Peace and Security Architecture, report for the Norwegian Peacebuilding Resource Centre (NOREF).

Anshan, L. 2005. African Studies in China in the Twentieth Century: A Historiographical Survey. African Studies Review, 48(1):59-87.

Anthony, R. and Hengkun, J. 2014. Security and engagement: the case of China and South Sudan. African East-Asian Affairs, 4:78-97.

Attree, L. 2012. China and conflict-affected states: Between principle and pragmatism. Sudan and South Sudan Case Study. London: Saferworld Publication.

AU (African Union). 2000. Constitutive Act of the African Union. Addis Ababa: African Union.

AU (African Union). 2010. African Peace and Security Architecture (APSA): 2010 
AFRICAN

Assessment Study, report commissioned by the African Union Peace and Security Department. Zanzibar, Tanzania.

AU (African Union). 2014. Agenda 2063 Vision and Action Plan [Online]. Available: http://agenda2063.au.int/en/about [2015, June 29].

AU (African Union). 2014. Joint Statement on Comprehensively Deepening ChinaAU Friendly Cooperation [Online]. Available: http://www.au.int/en/sites/ default/files/China-AU\%20Joint $\% 20$ Statement $\% 20$ on $\%$ 20Comprehensively\%20Deepening\%20China-AU\%20Friendly\% 20Coopertaion\%20-\%202.pdf [2014, December 31].

Benabdallah, L. 2014. Telephone interview with Chinese academic. 05 June 2014. Beijing, China.

Benabdallah, L. 2015. What's the deal with China's new Military Base in Djibouti? [Online]. Available: http://africasacountry.com/what-does-it-mean-thatchina-has-a-military-base-in-djibouti/ [2015, May 18].

Benabdallah , L. 2015b. Personal interview with AU officials. March 2015. African Union Headquarters, Addis Ababa, Ethiopia.

Bishop, B. 2013. A Highly Public Trip for China's President, and Its First Lady, New York Times [Online]. Available: http://dealbook.nytimes.com/2013/03/25/ china-dream-apple-nightmare/?_r $=0$ [2015, June 29].

Chinese Ministry of Foreign Affairs. 2014. New Asian Security Concept for New Progress in Security Cooperation [Online]. Available: http:// www.fmprc.gov.cn/mfa_eng/zxxx_662805/t1159951.shtml [2015, June 29].

Chinese Ministry of Foreign Affairs. China's Position Paper on the New Security Concept [Online]. Available: http://www.fmprc.gov.cn/ce/ceun/eng/xw/ t27742.htm [2015, June 29].

Duchâtel, M., Bräuner, O., and Hang, Z. 2014. Protecting China's Overseas Interests: The Slow Shift away from Non-interference. Stockholm International Peace Research Institute (SIPRI). Policy Paper 41, June. 
AFRICAN

EAST-ASIAN

AFFAIRS

FOCAC. Nd. Ministerial Conference Archives as well as official white papers and speech transcripts [Online]. Available: http://www.focac.org/eng/ltda/ [2015, June 29].

FOCAC. 2003. Forum on China-Africa Cooperation-Addis Ababa Action Plan [Online]. Available: http://www.fmprc.gov.cn/zflt/eng/zyzl/hywj/ t157710.htm [2015, June 29].

FOCAC. 2012. President Hu proposes measures in five priority areas to boost ChinaAfrica ties in Beijing [Online]. Available: http://www.focac.org/eng/ dwjbzjjhys/t953114.htm [2015, June 29].

Garwood-Gowers, A. 2012. China and the "Responsibility to Protect": the implications of the Libyan intervention. Asian Journal of International Law, 2 (2):375-393.

Hauauer, L. and Morris, L. 2014. Chinese Engagement in Africa: Drivers, Reactions, and Implications, for US Policy. International Security and Defense Policy Center: Rand Corporation.

Holsag, J. 2009. Embracing Chinese Global Security Ambitions. Washington Quarterly, 32(3): 105-118.

Jian, J. 2012. China in the International Conflict-management: Darfur as a Case. Global Review Winter, 7-11.

Large, D. 2008. China and the Contradictions of "Non-interference" in Sudan. Review of African Political Economy, 35(115): 93-106.

Large, D. 2009. China's Sudan engagement: changing Northern and Southern political trajectories in peace and war. China Quarterly, 199:610-26.

Large, D. 2012. Between the CPA and Southern independence: China's post-conflict engagement in Sudan. SAIIA Occasional Paper no. 115. Braamfontein: SAIIA

Leff, J., and LeBrun, E. 2014. Following the Thread: Arms and Ammunition Tracing 
AFRICAN

in Sudan and South Sudan. HSBA Working Paper 32, Small Arms Survey. Geneva: Graduate Institute of International and Development Studies. 9-125.

USNI News. 2015. Document: China's Military Strategy [Online]. Available: http:// news.usni.org/2015/05/26/document-chinas-military-strategy [2015, June 29].

Sautman, B., and Hairong, Y. 2014. Bashing 'the Chinese': contextualizing Zambia's Collum Coal Mine shooting. Journal of Contemporary China, 23(90):10731092 .

United Nations. Africa's Regional Economic Communities Briefing to UN Member States [Online]. Available: http://www.un.org/africa/osaa/reports/newreports/Background $\% 20$ Note $\% 20$ to $\% 20$ the $\% 20$ RECS $\% 20$ briefings $\% 20$ to $\%$ 20Member\%20States.pdf [2015, June 29].

Van Hoeymissen, S.2010. China's Support to Africa's Regional Security Architecture: Helping Africa to Settle Conflicts and Keep the Peace?. The China Monitor, 49:10-14.

Wang, Q.K. 2003. Hegemony and socialisation of the mass public: the case of postwar Japan's cooperation with the United States on China policy. Review of International Studies, 29:99-119.

Wang, Y. 2013. Creative Involvement: The Evolution of China's Global Role. Beijing: Peking University Press.

Wu, Z., and Taylor, I. 2011. From Refusal to Engagement: Chinese Contributions to Peacekeeping in Africa. Journal of Contemporary African Studies. 29(2):137154.

Xinhua News. 2015. Africa Focus: AU, EU conclude joint filed mission to Mali [Online]. Available: http://news.xinhuanet.com/english/africa/2015-02/15/ c_133998627.htm [2015, June 29].

$\mathrm{Xu}, \mathrm{W}$. 2012. Forum on China Africa Cooperation: Creating a more Mature and Efficient Platform. Contemporary International Relations, 32-42.

Xuejun, W. 2010. China's security cooperation with Africa under the frame of 
AFFAIRS

FOCAC. Paper presented to the conference on China, South Africa and Africa, SAIIA/ZNU.

Zhang, Z. 2014. Supporting African Renaissance: Chinese FM's four country Africa visit entrenches pragmatic foreign policy strategy. ChinAfrica Magazine [Online]. Available: http://www.chinafrica.cn/english/Cover/txt/2014-02/01/ content_593831.htm [2015, June 29]. 